\title{
KEDUDUKAN SHARIA COMPLIANCE PERBANKAN SYARIAH DI INDONESIA PERSPEKTIF YURIDIS-FILOSOFIS
}

\author{
Ni Nyoman Adi Astiti ${ }^{1}$
}

Sekolah Tinggi Ilmu Hukum Tambung Bungai Palangka Raya

Email: nyoman.stihtb@gmail.com

Jefry Tarantang ${ }^{2}$

Institut Agama Islam Negeri Palangka Raya

Email: jefry.tarantang@iain-palangkaraya.ac.id

\begin{abstract}
Sharia compliance is currently an important issue for sharia bank stakeholders in Indonesia. There have been many sharp criticisms from the public regarding the compliance of Islamic banks to Islamic principles, that Islamic banks in Indonesia are currently not compatible with sharia. This condition may be a positive impact of the increasingly massive socialization of Islamic banking to the public so that people are starting to become aware and have sufficient knowledge of Islamic banking, both from a juridical perspective as a regulatory framework and a solution to the legal vacuum of sharia banking regulations to ensure legal certainty, as well as a perspective. philosophical on the regulatory system that aims to create justice and benefit in Islamic banking practices.

Keywords: position, sharia compliance, sharia banking, juridical-philosophical.
\end{abstract}

\begin{abstract}
ABSTRAK
Kepatuhan syariah (sharia compliance) saat ini menjadi isu penting bagi stakeholders bank syariah di Indonesia. Banyak kritikan tajam dari masyarakat tentang kepatuhan bank syariah terhadap prinsip-prinsip syariah, bahwa bank syariah di Indonesia saat ini kurang sesuai syariah. Kondisi tersebut boleh jadi sebagai dampak positif dari semakin masifnya sosialisasi tentang perbankan syariah ke masyarakat sehingga masyarakat mulai sadar dan memiliki pengetahuan yang cukup tentang perbankan Syariah, baik dari perspektif yuridis sebagai tatanan regulasi dan solusi kekosongan hukum pengaturan perbankan syariah guna menjamin kepastian hukum, maupun perspektif filosofis pada tata regulasi yang bertujuan menciptakan keadilan dan kemanfaatan dalam praktek perbankan syariah.

Kata kunci: kedudukan, sharia compliance, perbankan syariah, yuridis-filosofis.
\end{abstract}

\footnotetext{
${ }^{1}$ Dosen Hukum Bisnis Sekolah Tinggi Ilmu Hukum Tambun Bungai Palangka Raya.

${ }^{2}$ Dosen Hukum Islam Fakultas Ekonomi dan Bisnis Islam IAIN Palangka Raya.
} 


\section{A. Pendahuluan}

Perkembangan ekonomi syariah dalam sepuluh tahun terakhir sedang mengalami kemajuan yang sangat pesat salah satunya adalah di Indonesia. Tidak dapat dipungkiri lagi bahwa dengan berkembangnya ekonomi syariah sekarang ini mulai banyak bermunculan lembaga-lembaga keuangan yang menggunakan prinsip syariah. Perkembangan bank syariah di Indonesia kini telah menjadi tolak ukur keberhasilan eksisitensi ekonomi syariah. Bank Muamalat sebagai bank syariah pertama dan menjadi pioner bagi bank syariah lainnya telah lebih dahulu menerapkan sistem ini ditengah menjamurnya bank-bank konvensional. Krisis keuangan global yang terjadi tahun 1998, krisis tahun 2008, dan krisis di Eropa tahun 2011, telah membuat industri perbankan Eropa anjlok dan menenggelamkan bank-bank konvensional dan banyak dilikuidasi karena kegagalan sistem bunganya, sementara perbankan yang menerapkan sistem syariah dapat tetap eksis dan mampu bertahan. ${ }^{3}$

Salah satu pilar penting dalam pengembangan bank syariah adalah syariah compliance. Pilar inilah yang menjadi pembeda utama antara bank syariah dengan bank konvensional. Untuk menjamin teraplikasinya prinsip-prinsip syariah di lembaga perbankan, diperlukan pengawasan syariah yang diperankan oleh Dewan Pengawas Syariah (DPS). Dalam pokok-pokok hasil penelitian Bank Indonesia menyatakan bahwa nasabah yang menggunakan jasa bank syariah, sebagian memiliki kecenderungan untuk berhenti menjadi nasabah antara lain karena keraguan akan konsistensi penerapan prinsip syariah. ${ }^{4}$ Selain perkembangan dalam dunia perbankan, masalah prinsip ekonomi syariah dan sharia compliance turut mewarnai dan mempengaruhi sektorsektor ekonomi lainnya, muncul pada dimensi nilai, dimensi konseptual maupun estabilish di masyarakat. ${ }^{5}$

Kepatuhan dan kesesuaian bank syariah terhadap prinsip syariah sering dipertanyakan oleh para nasabah. Secara implisit menunjukkan bahwa praktik perbankan syariah selama ini kurang memperhatikan prinsip-prinsip syariah, salah satu penyebab kepercayaan masyarakat pada bank syariah hal ini juga akan berdampak pada loyalitas masyarakat menggunakan jasa bank syariah. Peningkatan kepercayaan nasabah dapat digunakan sebagai indikator keberhasilan perkembangan bank syariah dan sekaligus sebagai prediksi keberhasilan bank syariah. ${ }^{6}$ Karenanya kepatuhan syariah merupakan pemenuhan terhadap prinsip syariah dalam sistem kerja yang dilakukan sebagai wujud dari karakteristik lembaga itu sendiri, terutama lembaga bank syariah. Dari sudut pandang masyarakat, khususnya pengguna jasa bank syariah; kepatuhan syariah merupakan inti dari integritas dan kredibilitas bank syariah. Mengingat keyakinan dan kepercayaan masyarakat kepada bank syariah didasarkan dan dipertahankan melalui pelaksanaan prinsip hukum Islam yang diadaptasi dari aturan operasionalisasi institusi tersebut. Sebab ketidakpatuhan terhadap prinsip syariah akan

\footnotetext{
${ }^{3}$ Novia, Peran Perbankan Syariah dalam Mengimplementasikan Keuangan Inklusif di Indonesia, Jurnal Etikonomi Vol. 14 No. 2 Oktober 2015, h. 222.

${ }^{4}$ Wulpiah, Urgensi Penerapan Kepatuhan Syariah Pada Perbankan Syariah (Telaah KonseptualAnalitis), Asy-Syar'iyyah: Jurnal Ilmu Syariah dan Perbankan Syariah, Vol. 2, No. 1 Tahun 2017, h. 101.

1.

${ }^{5}$ Ahmad Dakhoir, Hukum Syariah Compliance di Perbankan Syariah, Yogyakarta: K-Media, 2017, h.

${ }^{6}$ Aqidah Asri Suwarsi, Identifikasi Potensi Nasabah Baru Bank Syariah Ditinjau dari Customer Switching Intentation, Jurnal Ekonomi dan Bisnis Islam, Vol. 3, No. 2 Juli-Desember 2017, h. 170.
} 
berdampak negatif citra bank syariah dan berpotensi untuk ditinggalkan oleh nasabah potensial dan pengguna jasa bank syariah. ${ }^{7}$

Secara konseptual, industri keuangan syariah memang sesuai dengan tuntutan perkembangan zaman serta sudah menjadi kewajiban sejarahnya untuk lahir dan tumbuh menjadi sistem keuangan yang alternatif-solutif. Untuk merealisasikan hal ini bukanlah hal yang mudah, banyak tantangan dan rintangan yang harus di hadapi oleh industri keuangan syariah ke depan nanti. Industri keuangan syariah baik bank maupun nonbank saat ini masih dalam tahap awal evolusinya. Walaupun tingkat pertumbuhannya begitu cepat, sejauh ini baru menempati ceruk kecil (small niche) di sektor finansial di negeri-negeri muslim, apalagi disektor keuangan internasional. Meskipun terdapat sejumlah kesulitan, gerakan Islamisasi perbankan berjalan dengan baik. ${ }^{8}$

Kemajuan yang dicapai selama seperempat abad terakhir ini menunjukan hasil yang menggembirakan. Bank Syariah sampai pada Tahun 2015 telah mengalami perkembangan yang pesat. Secara kuantitatif, perkembangan bank syariah tersebut dapat dilihat dari jumlah Bank yang melaksanakan kegiatan usaha berdasarakan prinsip syariah dan dari sisi volume usaha. Sampai dengan Tahun 2015 terdapat 12 (dua belas) Bank Umum Syariah (BUS), 22 Unit Usaha Syariah (UUS) dan 161 Bank Pembiayaan Rakyat Syariah (BPRS). Secara keseluruhan jaringan kantor Bank Umum Syariah dan Unit Usaha Syariah berjumlah 2.881 Kantor. $^{9}$

Kehadiran Undang-undang No. 10 Tahun 1998 tentang perbankan, maka telah membuka kesempatan yang luas kepada perbankan syariah untuk berkembang. Undangundang ini bahkan tidak hanya menyebut bank syariah berdampingan dengan bank konvensional dalam pasal demi pasal, tetapi juga menyatakan secara rinci sistem produk-produk perbankan syariah. Produk-produk perbankan syariah harus sesuai dengan hukum syariah, hal inilah yang memungkinkan perbankan syariah menyesuaikan dengan menyesuaikan produk perbankan syariah yang akan bisa membawa dampak ketidak murnian produk syariah. ${ }^{10}$

Adanya Amandemen UU No. 7 Tahun 1992 yang menjadi UU No. 10 Tahun 1998 tentang Perbankan sebagai awal bagi beroperasinya perbankan syariah di Indonesia. Masih lemahnya peraturan yang ada di dalam UU tersebut, karena singkatnya aturan terkait perbankan yang menjalankan aktifitasnya di syariah, maka dikeluarkannya aturan dari Bank Indonesia dalam bentuk Peraturan Bank Indonesia (PBI) dan Surat Edaran Bank Indonesia (SEBI). Diterbitkannya Peraturan Bank Indonesia (PBI) No. 7/35/PBI/2005 tentang Perubahan Atas Peraturan Bank Indonesia No. 6/24/PBI/2004 tentang Bank Umum yang Melaksanakan Kegiatan Usaha Berdasarkan Prinsip Syariah, serta PBI No. 8/3/PBI/2006 tentang Perubahan Kegiatan Usaha Bank Umum Konvensional Menjadi Bank Umum yang Melaksanakan Kegiatan Usaha Berdasarkan Prinsip Syariah dan Pembukaan Kantor Bank yang Melaksanakan Kegiatan Usaha Berdasarkan Prinsip Syariah oleh Bank Umum Konvensional. Sehubungan dengan

\footnotetext{
${ }^{7}$ Wulpiah, Urgensi Penerapan Kepatuhan Syariah Pada Perbankan Syariah (Telaah KonseptualAnalitis), Asy-Syar'iyyah: Jurnal Ilmu Syariah dan Perbankan Syariah, Vol. 2, No. 1 Tahun 2017, h. 101-102.

${ }^{8}$ Moh. Indra Bangsawan, Eksistensi Ekonomi Islam (Studi Tentang Perkembangan Perbankan Syariah di Indonesia), Jurnal Law and Justice Vol. 2, No. 1 April 2017, h. 24-25.

${ }^{9}$ Moh. Indra Bangsawan, Eksistensi Ekonomi Islam (Studi Tentang Perkembangan Perbankan Syariah di Indonesia), Jurnal Law and Justice Vol. 2, No. 1 April 2017, h. 25.

${ }^{10}$ Abdul Azizs, Aplikasi Keuangan Syariah Pada Perbankan, Jurnal Perspektif Ekonomi Darussalam Vol. 2, No. 1 Maret 2016, h. 15-16.
} 
regulasi sebelumnya, maka diterbitkannya Undang-Undang No. 21 Tahun 2008 tentang Perbankan Syariah, yang lebih tegas dan terintegrasi dalam mengatur perbankan syariah yang ada di Indonesia. ${ }^{11}$

Pengembangan perbankan syariah, baik dari sisi produk, operasionalisasi, dan regulasi tentunya harus memenuhi prinsip kepatuhan syariah atau sharia compliance. Sebagai pilar penting dalam mengawal dan mengembangkan ekonomi syariah,, khususnya perbankan syariah di Indonesia maka dalam merumuskan setiap kegiatan perbankan syariah harus sesuai dengan sharia compliance. Untuk itu sharia compliance tentunya memiliki landasan dan keberlakuan hukum yang mengikat, baik secara yuridis dan filosofis dalam mengawal perkembangan dan pertumbuhan perbankan syariah secara sosiologis yang berkembang di masyarakat.

\section{B. Metode Penelitian}

Penelitian kedudukan sharia compliance perbankan syariah di Indonesia perspektif yuridis-filosofis merupakan penelitian hukum normatif yang dianalisis melalui pendekatan perundang-undangan (statute approach), ${ }^{12}$ pendekatan filosofis (philosophical approach) ${ }^{13}$ dan pendekatan konseptual (conceptual approach). ${ }^{14}$ Penelitian hukum normatif menggunakan bahan-bahan hukum berupa peraturan perundangan, seperti Undang-undang, hingga Peraturan Pemerintah. Pada penelitian ini seorang peneliti selalu mendasarkan pemikirannya pada aturan perundangan sebagai bahan hukum utama penelitian. Penelitian atas bahan-bahan hukum seperti perundanundangan dan putusan pengadilan tidak dapat dikategorikan sebagai sebuah penelitian sosial, mengingat ia memisahkan hukum dari segala bentuk analisis non hukum.

Kedudukan sharia compliance perbankan syariah di Indonesia perspektif yuridis-filosofis yang terbagi ke dalam beberapa pikiran, yaitu penulis melakukan elaborasi norma dan elaborasi doktrin terhadap kedudukan sharia compliance perbankan syariah di Indonesia, dan kemudian melakukan analisis hukum terhadap kedudukan sharia compliance perbankan syariah di Indonesia perspektif yuridisfilosofis dengan menggunakan penelitian normatif. Bahan hukum normatif yang dijadikan sebagai rujukan dalam penelitian ini terbagi kepada tiga bahan, yakni bahan primer, sekunder dan tertier. Bahan primer meliputi Undang-Undang (UU) Nomor 18 Tahun 2008 tentang Surat Berharga Syariah Negara (SBSN), UU No. 21 Tahun 2008 tentang Perbankan Syariah, Peraturan Bank Indonesia (PBI), Surat Edaran Bank Indonesia (SEBI), dan Fatwa Dewan Syariah Nasional Majelis Ulama Indonesia (DNS-

\footnotetext{
${ }^{11}$ Luqman Nurhisam, Kepatuhan Syariah (Sharia Compliance) dalam Industri Keuangan Syariah, Jurnal Hukum IUS QUIA IUSTUM No. 1, Vol. 23 Januari 2016, h. 81-82.

${ }^{12}$ Pendekatan perundang-undangan digunakan sebagai dasar awal menganalisis peraturan perundangundangan dan regulasi yang bersangkut paut dengan isu hukum, khususnya mengenai ratio legis (alasan mengapa ada ketentuan) dan dasar ontologis lahirnya suatu undang-undang. Lihat Hajar M. Model-Model Pendekatan dalam Penelitian Hukum dan Fiqh, Yogyakarta: Kalimedia, 2017, h. 70-71.

${ }^{13}$ Pendekatan filsafat hukum berusaha mengungkapkan hakikat hukum dengan menemukan landasan terdalam dari keberadaan hukum sejauh yang mampu dijangkau akal budi manusia. Lihat Fajlurrahman Jurdi, Logika Hukum, Jakarta: Kencana, 2017, h. 47. Lihat juga dalam Jefry Tarantang, Teori dan Aplikasi Pemikiran Kontemporer dalam Pembaruan Hukum Keluarga Islam, Jurnal Transformatif, Vol. 2, No. 1, April 2018, h. 29.

${ }^{14}$ Penelitian hukum dalam level dogmatik hukum atau penelitian hukum untuk keperluan praktik hukum tidak dapat melepaskan diri dari pendekatan perundang-undangan, dan pendekatan konseptual. Lihat Peter Mahmud Marzuki, Penelitian Hukum, Jakarta: Kencana, 2010, h. 94.
} 
MUI). ${ }^{15}$ Selain sumber primer tersebut, sebagai bahan pendukung digunakan pula sumber sekunder dan tertier. Sumber sekunder yaitu karya-karya atau teori-teori yang membahas sumber primer, seperti, peraturan perundang-undangan terkait, serta pemikiran para pakar. Adapun sumber tersier yaitu hal-hal yang mendukung sumber primer dan sekunder seperti, kamus dan sebagainya.

\section{Kedudukan Sharia Compliance dalam Praktek Perbankan Syariah di Indonesia}

Salah satu aspek hukum dalam perbankan syariah adalah regulasi tentang kepatuhan syariah (sharia compliance). Kepatuhan syariah adalah bagian penting bagi perbankan syariah dalam segi pengelolaan (manajemen) maupun operasionalnya. Hal itu didukung dengan mengharuskan keberadaaan Dewan Pengawas Syariah (DPS) bagi setiap institusi keuangan berbasis syariah. Dewan Pengawas Syariah (DPS) bertugas mengawasi penerapan kontrak atau akad apakah penerapannya sudah sesuai dengan prinsip-prinsip syariah.

Perangkat regulasi yang didesain secara spesifik untuk mengatur kepatuhan syariah tidak lagi dapat dihindari penyiapannya. Tuntutan untuk meningkatkan kerangka regulasi bagi kepatuhan syariah merupakan sebuah tantangan yuridis yang dihadapi oleh setiap negara yang berkeinginan untuk mengembangan bisnis keuangan berbasis Islam (syariah). Negara-negara tersebut ditantang untuk mereformulasi kerangka hukum mereka agar mampu secara sepenuhnya mengakomodasi kekhasan dari perbankan syariah. Selama kepatuhan terhadap prinsip-prinsip syariah merupakan keharusan bagi perbankan syariah, maka pengawasan (supervisory) syariah ada di Indonesia. Sehingga dapat dikatakan bahwa pengawasan syariah oleh Dewan Pengawas Syariah (DPS) merupakan bagian tak terpisahkan dari kepatuhan syariah. Dalam konteks ini, regulasi tentang pengawasan syariah, tentu saja mencakup di dalamnya keberadaan dewan syariah (sharia board), yang mana adalah bagian penting dari kerangka aturan-aturan regulasi sebagai kepatuhan syariah (sharia compliance). ${ }^{16}$

Secara umum sharia compliance adalah ketaatan bank syariah terhadap prinsipprinsip syariah. Bank syariah merupakan lembaga keuangan yang beroperasi sesuai dengan prinsip-prinsip syariah Islam, artinya bank dalam beroperasinya mengikuti ketentuan-ketentuan syariah Islam khususnya menyangkut tata-cara bermuamalat secara Islam. Prinsip utama bank syariah tercermin dalam produk-produk yang dihasilkannya bebas bunga dengan menggunakan prinsip bagi hasil. ${ }^{17}$

Menurut Adrian Sutedi, kepatuhan syariah secara operasional adalah kepatuhan kepada Fatwa Dewan Syariah Nasional (DSN) karena Fatwa DSN merupakan perwujudan prinsip dan aturan syariah yang harus ditaati dalam perbankan syariah. dalam operasional bank syariah tidak hanya meliputi produk saja, akan tetapi meliputi sistem, teknik dan identitas perusahaan. Karena itu, budaya perusahaan yang meliputi pakaian, dekorasi dan image perusahaan merupakan salah satu aspek kepatuhan syariah dalam bank syariah. Tujuannya, tidak lain untuk menciptakan suatu moralitas dan

\footnotetext{
${ }^{15}$ Ibnu Elmi Achmad Slamat Pelu, dan Jefry Tarantang, Fatwa Majelis Ulama Indonesia Sebagai Solusi Permasalahan Umat Islam di Indonesia, Al-Manahij: Jurnal Kajian Hukum Islam, Vol. 14 No. 2, Desember 2020, 307-316 DOI: https://doi.org/10.24090/mnh.v14i2.3927, h. 309.

${ }^{16}$ Luqman Nurhisam, Kepatuhan Syariah (Sharia Compliance) dalam Industri Keuangan Syariah, Jurnal Hukum IUS QUIA IUSTUM No. 1, Vol. 23 Januari 2016, h. 78-79.

${ }^{17}$ Wulpiah, Urgensi Penerapan Kepatuhan Syariah Pada Perbankan Syariah (Telaah KonseptualAnalitis), Asy-Syar'iyyah: Jurnal Ilmu Syariah dan Perbankan Syariah, Vol. 2, No. 1 Tahun 2017, h. $106-107$.
} 
spiritual kolektif, yang apabila digabungkan dengan produksi barang dan jasa, maka akan menopang kemajuan dan pertumbuhan jalan hidup yang islami. Kepatuhan syariah tersebut secara konsisten dijadikan sebagai kerangka kerja bagi sistem dan keuangan bank syariah dalam alokasi sumber daya, manajemen, produksi, aktivitas pasar modal dan distribusi kekayaan. ${ }^{18}$

Kepatuhan syariah adalah bagian dari pelaksanaan framework manajemen resiko, dan mewujudkan budaya kepatuhan dalam mengelola resiko perbankan Islam. Kepatuhan syariah (shariah compliance) juga memiliki standar internasional yang disusun dan ditetapkan oleh Islamic Financial Service Board (IFSB) dimana kepatuhan syariah merupakan bagian dari tata kelola lembaga (corporate governance). ${ }^{19}$ Kepatuhan syariah merupakan manifestasi pemenuhan seluruh prinsip syariah dalam lembaga yang memiliki wujud karakteristik, integritas dan Organisasi ini mempromosikan, meningkatkan performance dan stabilitas industri jasa keuangan Islam dengan menerbitkan standar global prinsip kehati-hatian dan panduan bagi industri secara luas yang mencakup perbankan, pasar modal dan sektor asuransi. Standar disusun oleh IFSB mengikuti proses hukum yang dituangkan dalam Pedoman dan Tata Cara Penyusunan standar/Pedoman, yang meliputi penerbitan draft paparan dan penyelenggaraan lokakarya dan, jika diperlukan, dengar pendapat publik. IFSB juga melakukan inisiatif penelitian dan koordinat pada industri-isu terkait, serta roundtables, seminar dan konferensi bagi regulator dan pemangku kepentingan industri, kredibilitas di bank syariah. Dimana budaya kepatuhan tersebut adalah nilai, perilaku dan tindakan yang mendukung terciptanya kepatuhan bank syariah terhadap seluruh ketentuan Bank Indonesia. ${ }^{20}$

Konsep dasar fungsi kepatuhan berfungsi sebagai pelaksana dan pengelola risiko kepatuhan yang berkoordinasi dengan satuan kerja dalam manajemen resiko. Fungsi kepatuhan melakukan tugas pengawasan yang bersifat preventif dan menjadi elemen penting dalam pengelolaan dan operasional bank syariah, pasar modal, asuransi syariah, pegadaian syariah serta lembaga keuangan syariah non bank (koperasi jasa keuangan syariah). Hal ini dilakukan untuk memastikan bahwa kebijakan, ketentuan, sistem dan prosedur yang dilakukan oleh perbankan Islam telah sesuai dengan ketentuan dan peraturan perundang-undangan Bank Indonesia, Pemerintah, Bapepam-LK, Fatwa MUI, serta penetapan hukum yang telah ditetapkan dalam standar internasional Syariah Supervisory Board (SSB). ${ }^{21}$

Kewenangan dalam melakukan pengawasan terhadap kepatuhan syariah adalah Dewan Pengawas Syariah (DPS).15 Dewan Pengawas Syariah melengkapi tugas pengawasan yang diberikan oleh komisaris, dimana kepatuhan syariah semakin penting untuk dilakukan dikarenakan adanya permintaan dari nasabah agar bersifat inovatif dan berorientasi bisnis dalam menawarkan instrumen dan produk baru serta untuk

\footnotetext{
${ }^{18}$ Ibid., h. 107-108.

${ }^{19}$ IFSB adalah organisasi penetapan standar internasional, diresmikan tanggal 3 November 2002 dan mulai beroperasi pada tanggal 10 Maret 2003.

${ }^{20}$ Bank Indonesia, Peraturan Bank Indonesia Nomor 13/2/PBI/2011 Tentang Pelaksanaan Fungsi Kepatuhan Bank Umum, Tanggal 12 Januari 2011.

${ }^{21}$ Haniah Ilhami, Pertanggungjawaban Dewan Pengurus Syariah Sebagai Otoritas Pengawas Kepatuhan Syariah Bagi Bank Syariah, Jurnal Mimbar Hukum, Volume 21 Nomor 3, Oktober 2009, h. 477.
} 
memastikan kepatuhan terhadap hukum Islam. ${ }^{22}$ Dewan pengawas syariah (DPS) terdiri dari pakar syariah yang mengawasi aktivitas dan operasional institusi finansial untuk memastikan kepatuhan terhadap prinsip-prinsip syariah. Dewan syariah mengemban tugas dan tanggungjawab besar dan berfungsi sebagai bagian stakeholders, karena mereka adalah pelindung hak investor dan pengusaha yang meletakkan keyakinan dan kepercayaan dalam institusi finansial. Keberadaan dewan pengawas syariah memiliki lima isu tata kelola perusahaan, yaitu independen, kerahasiaan, kompetensi, konsistensi dan keterbukaan. ${ }^{23}$

Kepatuhan syariah harus menekankan pada peran aktif dari seluruh elemen organisasi kepatuhan dalam lembaga, yang terdiri dari Direktur yang membawahkan fungsi kepatuhan di Bank Islam, Kepala unit kepatuhan dan satuan kerja kepatuhan untuk mengelola risiko kepatuhan. Kepatuhan merupakan tanggung jawab bersama yang dilaksanakan oleh seluruh karyawan bank, dari atasan sampai bawahan (topdown). Berbagai pengaturan dalam undang-undang maupun PBI sudah ditetapkan sebagai regulasi pengembangan perbankan syariah di Indonesia, seperti UndangUndang No. 21 Tahun 2008 tentang Perbankan Syariah, yang secara lebih tegas dan integratif mengatur perbankan syariah di Indonesia. ${ }^{24}$ Pengaturan hukum kepatuhan syariah juga sudah ditetapkan oleh Bank Indonesia, yaitu melalui Peraturan Bank Indonesia Nomor 13/2/PBI/2011 Tentang Pelaksanaan Fungsi Kepatuhan Bank Umum yang ditetapkan pada tanggal 12 Januari 2011 dan berlaku sejak tanggal 1 September 2011.

Fungsi kepatuhan yaitu merumuskan strategi guna mendorong terciptanya budaya kepatuhan bank, membuat kebijakan kepatuhan atau prinsip-prinsip kepatuhan, menetapkan sistem dan prosedur kepatuhan yang akan digunakan untuk menyusun ketentuan dan pedoman internal bank, memastikan bahwa seluruh kebijakan, ketentuan, sistem, dan prosedur, serta kegiatan usaha yang dilakukan bank, meminimalkan risiko kepatuhan bank, melakukan tindakan pencegahan agar kebijakan dan/atau keputusan yang diambil direksi bank atau pimpinan kantor cabang bank asing tidak menyimpang dari ketentuan Bank Indonesia dan peraturan perundang- undangan yang berlaku serta melakukan tugas-tugas lainnya yang terkait dengan fungsi kepatuhan. Bank Indonesia sebagai regulator, perlu mencermati concern terhadap berbagai isu seputar perbankan beberapa waktu terakhir, antara lain aspek integritas pengelolaan bank menjadi sangat penting, aspek transparansi dan edukasi nasabah, karena sistem pengelolaan risiko maupun pengawasan yang ketat belum tentu efektif dalam mencegah penyalahgunaan yang dilakukan oleh pengelola bank yang sengaja memanfaatkan celah kelemahannya. Bank Indonesia harus memperkuat screening berdasarkan karakter dan integritas serta kompetensi para bankir. ${ }^{25}$

Efektivitas kepatuhan syariah dibangun dengan beberapa upaya, yaitu Protektif, yaitu memastikan terciptanya ketaatan Bank terhadap kebijakan, ketentuan, dan

\footnotetext{
${ }^{22}$ Hennie Van Greuning dan Zamir Iqbal, Analisis Risiko Perbankan Syariah (Risk Analysis For Islamic Banks), Jakarta: Salemba Empat, 2011, h. 177.

${ }^{23}$ Zamir Iqbal dan Abbas Mirakhor, Pengantar Keuangan Islam: Teori dan Praktek, terj. Oleh A.K. Anwar, Jakarta: Prenada Media Group, 2008, h. 365.

${ }^{24}$ Agus Triyanta, Implementasi Kepatuhan Syariah dalam Perbankan Islam (Syariah) (Studi Perbandingan antara Malaysia dan Indonesia), Jurnal Hukum No. Edisi Khusus Volume 16, Oktober 2009, h. 217.

${ }^{25}$ Direktorat Perbankan Syariah, Outlook Perbankan Syariah Indonesia, 2012, Bank Indonesia, h. 28.
} 
peraturan yang berlaku melalui analisis di bidang keuangan, akuntansi, operasional dan kegiatan lainnya dalam pemeriksaan (on-site) maupun pengawasan (off-site); Konstruktif, yaitu menjaga tingkat kehematan penggunaan sumberdaya dan efektivitas hasil yang maksimal melalui saran perbaikan dan informasi obyektif untuk melakukan review pada semua tingkatan manajemen; Konsultatif, yaitu memberikan rekomendasi yang bermanfaat bagi seluruh manajemen sebagai penyempurnaan kebijakan dalam rangka mencapai tujuan organisasi melalui identifikasi segala kemungkinan risiko dan penyimpangan untuk memperbaiki dan meningkatkan efisiensi penggunaan sumberdaya dan dana, sehingga penyimpangan dapat terdeteksi. ${ }^{26}$

Demi menjawab tantangan mengembangkan produk syariah, ada empat hal yang bisa dilakukan pelaku perbankan, yaitu operating philosophy, organization structure, experience effect, dan management style. Hal ini memiliki peran signifikan untuk pertumbuhan pangsa pasar syariah, termasuk pengembangan dan inovasi produk dan merupakan satu bagian dari fungsi research and development serta brand experience yang mampu memberi wawasan yang intens pada masyarakat tentang produk syariah. ${ }^{27}$

Kepatuhan syariah merupakan bagian dari sistem tata kelola perbankan syariah yang baik. Pengelolaan bank Syariah tidak bisa lepas dari pemenuhan prinsip-prinsip syariah, terutama dalam pelaksanaan fungsi intermediasi. Pada tataran operasional pengumpulan dan penyaluran dana masyarakat harus menerapkan prinsip-prinsip syariah. Kepatuhan syariah merupakan salah satu unsur dalam penilaian mengenai tingkat kesehatan bank Syariah. Pemeliharaan tingkat kesehatan bank akan berbanding lurus dengan pemeliharaan kepercayaan masyarakat, sehingga bila bank lalai dalam menjaga tingkat kesehatanannya karena tidak menerapkan prinsip syariah, maka kepercayaan masyarakat terhadap bank akan hilang. Dalam perspektif Perbankan Syariah, kepatuhan Syariah adalah meningkatkan pengetahuan syariah dan menciptakan inovasi produk dan layanan kreatif dengan tetap patuh pada aturan DSN. Peran DPS yang belum optimal dapat berdampak terhadap risk management. Jenis manajemen risiko yang terkait erat dengan peran DPS adalah risiko reputasi yang selanjutnya berdampak pada displaced commercial risk, seperti risiko likuiditas dan risiko lainnya. Langkah pengutan peran DPS dapat ditempuh melalui berbagai aspek di antaranya mempertegas kompetensi keilmuan DPS, mempertegas batasan maksimal jabatan DPS, dan evaluasi peran DPS pada bank Syariah oleh Majelis Ulama Indonesia dan Bank Indonesia. ${ }^{28}$

\section{Kedudukan Sharia Compliance dalam Praktek Perbankan Syariah di Indonesia} Perspektif Yuridis-Filosofis

Undang-Undang No. 40 Tahun 2007 tentang Perseroan Terbatas dan UndangUndang No. 21 Tahun 2008 tentang Perbankan Syariah. Kedua Undang-Undang ini merupakan landasan yuridis yang cukup kuat bagi keberadaan DPS untuk menjamin terimplementasinya syariah compliance di lembaga perbankan dan keuangan syariah.

Menurut Undang-Undang No. 40 Tahun 2007 tentang Perseroan Terbatas Pasal

${ }^{26}$ Bank Syariah Mandiri, Laporan Pelaksanaan Good Corporate Governance, Tahun 2011, h. 64.

${ }^{27}$ Agus Waluyo, Kepatuhan Bank Syariah Terhadap Fatwa Dewan Syariah Nasional Pasca Transformasi ke dalam Hukum Positif, Jurnal Penelitian Sosial IAIN Salatiga, Vol. 10, No. 2, Desember 2016, h. 530 .

${ }^{28}$ Wulpiah, Urgensi Penerapan Kepatuhan Syariah Pada Perbankan Syariah (Telaah KonseptualAnalitis), Asy-Syar'iyyah: Jurnal Ilmu Syariah dan Perbankan Syariah, Vol. 2, No. 1 Tahun 2017, h. 109-110. 
109 menyebutkan:

1. Perseroan yang menjalankan kegiatan usaha berdasarkan prinsip syariah selain mempunyai Dewan Komisaris wajib mempunyai Dewan Pengawas Syariah.

2. Dewan Pengawas Syariah sebagaimana dimaksud pada ayat (1) terdiri atas seorang ahli syariah atau lebih yang diangkat oleh RUPS atas rekomendasi Majelis Ulama Indonesia.

3. Dewan Pengawas Syariah sebagaimana dimaksud pada ayat (1) bertugas memberikan nasihat dan saran kepada Direksi serta mengawasi kegiatan Perseroan agar sesuai dengan prinsip syariah. ${ }^{29}$

Disebutkan juga dalam Undang-Undang No. 21 Tahun 2008 tentang Perbankan Syariah Pasal 32:

1. Dewan Pengawas Syariah wajib dibentuk di Bank Syariah dan Bank Umum Konvensional yang memiliki UUS.

2. Dewan Pengawas Syariah sebagaimana dimaksud pada ayat (1) diangkat oleh Rapat Umum Pemegang Saham atas rekomendasi Majelis Ulama Indonesia

3. Dewan Pengawas Syariah sebagaimana dimaksud pada ayat (1) bertugas memberikan nasihat dan saran kepada direksi serta mengawasi kegiatan Bank agar sesuai dengan Prinsip Syariah.

4. Ketentuan lebih lanjut mengenai pembentukan Dewan Pengawas Syariah sebagaimana dimaksud pada ayat (1) diatur dengan Peraturan Bank Indonesia. $^{30}$

Kepatuhan syariah pada bank syariah terutama persoalan market share dan penurunan kepatuhan terhadap prinsip-prinsip syariah, idealnya harus diawali dengan mengimplementasikan shariah governance sehingga akan berdampak pada peningkatan kepercayaan pada bank syariah yang pada akhirnya akan meningkatkan market share bank syariah. Tujuannya antara lain:

1. Memberikan pemahaman bagi regulator dan pelaku industri perbankan syariah tentang implementasi shariah governance pada bank syariah serta implikasinya terhadap kepercayaan nasabah;

2. Memberikan dasar pertimbangan dalam rangka perumusan langkah strategi untuk menyempurnakan kebijakan pengembangan oleh Bank Indonesia maupun strategi penguasaan pasar oleh masing-masing bank syariah. ${ }^{31}$

Lebih lanjut sebagai upaya membangun budaya kepatuhan syariah pada bank syariah seyogyanya dapat melakukan langkah-langkah untuk mendukung terciptanya budaya kepatuhan, di antaranya:

1. Penerbitan piagam kepatuhan, yakni dokumen kepatuhan yang bersifat strategis dan berisi panduan, peraturan, kaidah dan kebijakan bank yang wajib dipatuhi oleh seluruh jajaran bank syariah;

\footnotetext{
${ }^{29}$ Pasal 109 Undang-Undang No. 40 Tahun 2007 tentang Perseroan Terbatas.

${ }^{30}$ Pasal 32 Undang-Undang No. 21 Tahun 2008 tentang Perbankan Syariah.

${ }^{31}$ Wulpiah, Urgensi Penerapan Kepatuhan Syariah Pada Perbankan Syariah (Telaah KonseptualAnalitis), Asy-Syar'iyyah: Jurnal Ilmu Syariah dan Perbankan Syariah, Vol. 2, No. 1 Tahun 2017, h. 117.
} 
2. Penerbitan kebijakan kepatuhan, yakni rangkaian asas yang menjadi garis besar dan dasar pelaksanaan fungsi kepatuhan bank;

3. Sistem kepatuhan bank, yakni perangkat pendukung yang telah ditetapkan oleh bank dalam bentuk standar manual kerja maupun yang berbasis teknologi untuk mendukung pelaksanaan kepatuhan bank syariah. Sistem kepatuhan bank syariah meliputi: standar prosedur kerja, ketersediaan unit pelaksana fungsi kepatuhan bank dan tersedianya sistem informasi kepatuhan atau media pendukung pelaksana kepatuhan bank syariah; dan

4. Kerangka berpikir, yakni cara pandang dan perilaku jajaran bank dalam menjalankan tugas sehari hari untuk senantiasa mengedepankan prudensialitas, ketaatan pada kepatuhan dan menghindarkan penyimpangan, tidak mengorbankan kualitas dengan kuantitas, tidak menyalahi wewenang, tidak melemahkan pengendalian internal dan tidak mengabaikan risiko kepatuhan dengan eksepsi yang berlebihan. ${ }^{32}$

Regulasi kepatuhan syariah diawali dengan aturan terhadap perbankan yang menjalankan aktifitasnya di bidang syariah. Sesuai dengan amandemen UU No. 7 Tahun 1992 yang menjadi UU No. 10 Tahun 1998 tentang Perbankan sebagai awal bagi beroperasinya perbankan syariah di Indonesia. Masih lemahnya peraturan yang ada di dalam UU tersebut, karena singkatnya aturan terkait perbankan yang menjalankan aktifitasnya di syariah, maka dikeluarkannya aturan dari Bank Indonesia dalam bentuk Peraturan Bank Indonesia (PBI) dan Surat Edaran Bank Indonesia (SEBI). Diterbitkannya Peraturan Bank Indonesia (PBI) No. 7/35/PBI/2005 tentang Perubahan Atas Peraturan Bank Indonesia No. 6/24/PBI/2004 tentang Bank Umum yang Melaksanakan Kegiatan Usaha Berdasarkan Prinsip Syariah, serta PBI No. 8/3/PBI/2006 tentang Perubahan Kegiatan Usaha Bank Umum Konvensional Menjadi Bank Umum yang Melaksanakan Kegiatan Usaha Berdasarkan Prinsip Syariah dan Pembukaan Kantor Bank yang Melaksanakan Kegiatan Usaha Berdasarkan Prinsip Syariah oleh Bank Umum Konvensional. Sehubungan dengan regulasi sebelumnya, maka diterbitkannya UU No. 21 Tahun 2008 tentang Perbankan Syariah, yang lebih tegas dan terintegrasi dalam mengatur perbankan syariah yang ada di Indonesia. ${ }^{33}$ Selanjutnya beraneka ragam regulasi terkait pengembangan aturan seiring dengan kemajuan perbankan syariah, berikut aturan dari Bank Indonesia baik dari PBI maupun dalam bentuk SEBI yaitu:

1. Surat Edaran Bank Indonesia No. 11/9/DPbS tanggal 7 April 2009 perihal Bank Umum Syariah;

2. Surat Edaran Bank Indonesia Nomor 11/28/DPbS tanggal 5 Oktober 2009 perihal Unit Usaha Syariah;

3. Peraturan Bank Indonesia Nomor 11/3/PBI/2009 tentang Bank Umum Syariah;

4. Peraturan Bank Indonesia Nomor 11/10/PBI/2009 tentang Unit Usaha Syariah;

\footnotetext{
${ }^{32}$ Ibid., h. 118.

${ }^{33}$ Luqman Nurhisam, Kepatuhan Syariah (Sharia Compliance) dalam Industri Keuangan Syariah, Jurnal Hukum IUS QUIA IUSTUM No. 1, Vol. 23 Januari 2016, h. 81-82.
} 
5. Surat Edaran Bank Indonesia Nomor 15/50/DPbS tentang Perubahan Atas Surat Edaran Bank Indonesia No. 11/9/DPbS tanggal 7 April 2009 perihal Bank Umum Syariah;

6. Surat Edaran Bank Indonesia Nomor 15/51/DPbS tentang Perubahan Atas Surat Edaran Bank Indonesia Nomor 11/28/DPbS tanggal 5 Oktober 2009 perihal Unit Usaha Syariah;

7. Peraturan Bank Indonesia Nomor 15/13/PBI/2013 tentang Perubahan Atas Peraturan Bank Indonesia Nomor 11/3/PBI/2009 tentang Bank Umum Syariah;

8. Peraturan Bank Indonesia Nomor 15/14/PBI/2013 tentang Perubahan Atas Peraturan Bank Indonesia Nomor 11/10/PBI/2009 tentang Unit Usaha Syariah;

9. Surat Edaran Bank Indonesia Nomor 15/44/DPbS tentang Fasilitas Pendanaan Jangka Pendek Syariah bagi Bank Umum Syariah;

10. Surat Edaran Bank Indonesia Nomor 15/26/DPbS tentang Pelaksanaan Pedoman Akuntansi Perbankan Syariah Indonesia;

11. Surat Edaran Bank Indonesia Nomor 15/22/DPbS tentang Pedoman Pelaksanaan Tugas dan Tanggung Jawab Dewan Pengawas Syariah Bank Pembiayaan Rakyat Syariah;

12. Surat Edaran Bank Indonesia Nomor 15/8/DPbS tentang Pembukaan Jaringan Kantor Bank Umum Syariah dan Unit Usaha Syariah Berdasarkan Modal Inti;

13. Peraturan Bank Indonesia Nomor 14/20/PBI/2012 tentang Perubahan Peraturan Bank Indonesia Nomor 11/24/PBI/2009 tentang Fasilitas Pendanaan Jangka Pendek Syariah Bagi Bank Umum Syariah; dan

14. Surat Edaran Bank Indonesia Nomor 14/33/DPbS tentang Penerapan Kebijakan Produk Pembiayaan Kepemilikan Rumah dan Pembiayaan Kendaraan Bermotor bagi Bank Umum Syariah dan Unit Usaha Syariah. ${ }^{34}$

Regulasi di atas tidak menutup aturan-aturan sebelumnya, karena aturan-aturan sebelum undang-undang ini lahir masih tetap berlaku sepanjang hal-hal yang tidak diatur dalam undang-undang ini. selanjutnya, aspek lain yang penting untuk menunjang regulasi perbankan syariah adalah dikeluarkannya aturan-aturan berdasarkan prinsip syariah dalam bentuk fatwa-fatwa oleh DSN-MUI. Lebih lanjut mengenai kepatuhan syariah di Indonesia secara yuridis konstitusional dapat dilihat dalam ketentuan Pasal 29 ayat (1) UUD 1945 dengan tegas menyatakan bahwa Negara berdasar atas Ketuhanan Yang Maha Esa, pada dasarnya mengandung tiga makna, yaitu:

1. Negara tidak boleh membuat peraturan perundang-undangan atau melakukan kebijakan-kebijakan yang bertentangan dengan dasar keimanan kepada Tuhan Yang Maha Esa;

2. Negara berkewajiban membuat peraturan perundang-undangan atau melakukan kebijakan-kebijakan bagi pelaksanaan wujud rasa keimanan kepada Tuhan Yang Maha Esa dari segolongan pemeluk agama yang memerlukannya;

\footnotetext{
${ }^{34} I b i d .$, h. 82-83.
} 
3. Negara berkewajiban membuat peraturan perundang-undangan yang melarang siapa pun melakukan pelecehan terhadap ajaran agama (paham ateisme). ${ }^{35}$

Menurut Pasal 29 ayat (2) UUD 1945 disebutkan bahwa negara menjamin kemerdekaan tiap-tiap penduduk untuk memeluk agamanya masing-masing dan untuk beribadat menurut agama dan kepercayaannya itu. Kata "menjamin” sebagaimana termaktub dalam ayat (2) Pasal 29 UUD 1945 tersebut bersifat “imperatif”, artinya negara berkewajiban secara aktif melakukan upaya-upaya agar tiap-tiap penduduk dapat memeluk agama dan beribadat menurut agama dan kepercayaannya itu. Sebenarnya, melalui ketentuan Pasal 29 ayat (2) UUD 1945 menjamin untuk terwujudnya pelaksanaan untuk pemenuhan seluruh syariat Islam bagi umat Islam dalam berbagai aspek kehidupan umat Islam yang pada dasarnya dapat dijalankan secara sah dan formal oleh kaum muslimin, baik secara langsung maupun tidak langsung, dengan jalan diadopsi dalam hukum positif nasional. ${ }^{36}$ Dengan begitu jelas bahwa kedudukan kepatuhan syariah dalam praktek perbankan syariah dijamin secara yuridis konstitusional dan juga yuridis filosofis sebagaimana elaborasi normanya terwujud dalam Undang-Undang No. 21 Tahun 2008 tentang Perbankan Syariah.

Berdasarkan aspek politik hukum lahirnya Undang-undang Perbankan Syariah Nomor 21 Tahun 2008, masih menyisakan pekerjaan rumah di antaranya tahap yuridis, tahap kelembagaan dan tahap mekanik. Tahap yuridis, memfokuskan pada bagaimana hukum yang tertulis (legal formal) dapat berjalan, ditegakan di tengah-tengah masyarakat untuk mencapai keadilan. Tentu aspek penegak hukum yang oleh Friedman dipengaruhi oleh sub sistem substansi, struktur dan kultur yang akan menjawab efektif tidaknya suatu perundang-undangan. Oleh karena itu dalam tahap ini ada kaitan erat dengan asas-asas hukum yang lazim kita kenal dengan istilah nilai dasar hukum yaitu: kemanfaatan, keadilan dan kepastian hukum. ${ }^{37}$

Undang-undang perbankan syariah, jika diteropong dari aspek yuridis merupakan hukum yang baik, karena hukum yang baik adalah hukum yang mempunyai kekuatan yuridis yang memberikan kepastian hukum. Dalam rangka mewujudkan kepastian hukum unsur penegakan hukum dari Friedman (substansi, struktur dan kultur) penekanan unsur manusia merupakan pelaku utama dalam segala kegiatan untuk mewujudkan keadilan. Pendekatan hukum yang bersifat empirik positivistik tidak cukup untuk mewujudkan keadilan, tetapi proses interaksi antara manusia dengan lingkungan yang dilandasi dengan budaya akan lebih menjadi bermakna. Dalam hal ini maka pemahaman hukum melalui pengalaman internal para subyek pelaku dan hukum

${ }^{35}$ Akhyar Ari Gayo, dkk, Kedudukan Fatwa MUI dalam Upaya Mendorong Pelaksanaan Ekonomi Syariah, Jakarta: Badan Pembinaan Hukum Nasional Kementerian Hukum dan HAM RI, 2013, h. 79-80. Lihat juga dalam Ibnu Elmi Achmad Slamat Pelu, dan Jefry Tarantang, Fatwa Majelis Ulama Indonesia Sebagai Solusi Permasalahan Umat Islam di Indonesia, Al-Manahij: Jurnal Kajian Hukum Islam, Vol. 14 No. 2, Desember 2020, 307-316 DOI: https://doi.org/10.24090/mnh.v14i2.3927, h. 314.

${ }^{36}$ Akhyar Ari Gayo, dkk, Kedudukan Fatwa MUI dalam Upaya Mendorong Pelaksanaan Ekonomi Syariah, Jakarta: Badan Pembinaan Hukum Nasional Kementerian Hukum dan HAM RI, 2013, h. 80.

${ }^{37}$ M. Ali Mansyur, Aspek Hukum Perbankan Syariah dan Implementasinya di Indonesia, Jurnal Dinamika Hukum, Vol. 11 Edisi Khusus Februari 2017, h. 71. 
merupakan makna mereka. Berdasarkan pemahaman (verstehen) dan interpretasi, kita dapat menangkap makna, nilai-nilai dibalik perilaku mereka. Karenanya kajian yang digunakan bukan lagi semata-mata yuridis dogmatik melainkan pendekatan sosio legalantro yang diorientasi pada fungsionalisasi hukum. ${ }^{38}$

Undang-undang Nomor 21 Tahun 2008 tentang Perbankan Syariah (UUPS), keberadaannya sesungguhnya merupakan tuntutan untuk memenuhi apabila dilihat aspek filosofis menunjukan bahwa perkembangan kebutuhan hukum masyarakat (muslim khususnya) terhadap kesadaran menjalankan syariat Islam sebagai konsekuensi dari keyakinannya semakin tinggi. Ini berarti bahwa pluralisme hukum harus diterima sebagai realitas (Real of Entity) yang majemuk (legal fluraly) dalam kehidupan bermasyarakat, sebagaimana diungkapkan oleh Cotterral: 1995 "We should think of law as a phenomenon pluralistically, as a regulation of many krud existing in a veriety of relationships, same of the quit tenuous, with the primary legal institutions of the centralized state". ${ }^{39}$

Keberadaan bank syariah sesungguhnya ditujukan untuk memenuhi kebutuhan masyarakat muslim atas pelaksanaan ajaran Islam secara menyeluruh termasuk dalam kegiatan penyaluran dananya. Kepercayaan dan keyakinan masyarakat pada bank syariah lebih didasarkan pada pelaksanaan prinsip hukum Islam yang diadopsi dalam aturan operasional institusi, sehingga dibutuhkan kepatuhan terhadap prinsip-prinsip syariah. Tanpa adanya kepatuhan terhadap prinsip syariah, maka dapat berpengaruh pada keputusan masyarakat untuk memanfaatkan jasa yang diberikan bank syariah. Dari sudut pandang ini, maka kepatuhan syariah merupakan inti dari integritas dan kredibilitas bank Syariah.

Kepatuhan syariah merupakan konsekuensi logis penggunaan pedomanpedoman yang secara legal formal disepakati sebagai pedoman dan menjadi syarat mutlak bagi bank syariah dalam menjalankan usahanya. Dalam upaya pemenuhan terhadap nilai-nilai syariah, bank Syariah harus menjadikan fatwa DSN dan PBI sebagai alat ukur pemenuhan prinsip syariah, baik dalam produk, transaksi, maupun dan operasionalnya. Secara operasional, kepatuhan bank Syariah terhadap fatwa DSN sebagai perwujudan prinsip dan aturan syariah harus ditaati. Menurut Sutedi, kepatuhan syariah dalam operasional bank syariah tidak hanya meliputi produk saja, akan tetapi meliputi sistem, teknik, dan identitas perusahaan. Karena itu, budaya perusahaan merupakan salah satu aspek kepatuhan syariah dalam bank syariah. Hal ini bertujuan untuk menciptakansuatu moralitas dan spiritual kolektif, yang apabila digabungkan dengan produksi barang dan jasa, maka akan menopang kemajuan dan pertumbuhan bank syariah. Kepatuhan bank Syariah terhadap peraturan perundangundangan dipandang telah berjalan cukup efektif. Menurut Bank Indonesia, kepatuhan bank Syariah terhadap peraturan perundang-undangan dapat dilihat laporan tahunannya. Sebagai pemeriksa, BI telah mengungkapkan bahwa dalam penyaluran dana pembiayaan, bank Syariah tidak melakukan pelanggaran dalam penyaluran dana. Kepatuhan tersebut juga tercermin dalam susunan mengenai komite-komite penunjang

${ }^{38}$ Sajipto Rahardjo, 2007, Menggagas Hukum Progresif, Semarang: Pustaka Pelajar, h. 10. Lihat juga dalam M. Ali Mansyur, Aspek Hukum Perbankan Syariah dan Implementasinya di Indonesia, Jurnal Dinamika Hukum, Vol. 11 Edisi Khusus Februari 2017, h. 70.

${ }^{39}$ M. Ali Mansyur, Aspek Hukum Perbankan Syariah dan Implementasinya di Indonesia, Jurnal Dinamika Hukum, Vol. 11, Edisi Khusus Februari 2017, h. 69. 
Dewan Komisari seperti Komite Audit, Komite Pemantau Risiko, dan Komite Remunerasi dan Nominasi, fungsi dan mekanisme kerja masing-masing, rapat-rapat yang dilakukan, serta laporan kinerjanya. ${ }^{40}$

\section{E. Kesimpulan}

Kedudukan sharia compliance dalam praktek perbankan syariah di Indonesia yaitu menjadi seperangkat aturan yang mengikat dan memaksa untuk dipatuhi oleh lembaga keuangan syariah. Melalui Undang-Undang Nomor 21 Tahun 2008 tentang Perbankan Syariah, lahir kewajiban bagi Bank Indonesia sebagai regulator agar materi muatan yang terkandung dalam Fatwa DSN-MUI dapat diserap dan ditransformasikan dalam merumuskan prinsip-prinsip syariah dalam bidang perekonomian dan keuangan syariah menjadi materi muatan Peraturan Perundang-undangan yang memiliki kekuatan hukum dan mengikat umum. Pada praktek perbankan syariah dampak positif dari semakin masifnya sosialisasi tentang perbankan syariah ke masyarakat sehingga masyarakat mulai sadar dan memiliki pengetahuan yang cukup tentang perbankan syariah, baik dari perspektif yuridis sebagai tatanan regulasi dan solusi kekosongan hukum pengaturan perbankan syariah guna menjamin kepastian hukum. Sedangkan dalam perspektif filosofis pada tata regulasi yang bertujuan menciptakan keadilan dan kemanfaatan dalam praktek perbankan syariah yang memiliki tujuan menjamin kepastian hukum bagi stakeholders dan sekaligus memberi keyakinan kepada masyarakat untuk mengunakan produk dan jasa perbankan syariah serta menjamin stabilitas sistem keuangan.

\section{F. Daftar Pustaka}

Abdul Azizs, Aplikasi Keuangan Syariah Pada Perbankan, Jurnal Perspektif Ekonomi Darussalam Vol. 2, No. 1 Maret 2016.

Agus Triyanta, Implementasi Kepatuhan Syariah dalam Perbankan Islam (Syariah) (Studi Perbandingan antara Malaysia dan Indonesia), Jurnal Hukum No. Edisi Khusus Volume 16, Oktober 2009.

Agus Waluyo, Kepatuhan Bank Syariah Terhadap Fatwa Dewan Syariah Nasional Pasca Transformasi ke dalam Hukum Positif, Jurnal Penelitian Sosial IAIN Salatiga, Vol. 10, No. 2, Desember 2016.

Ahmad Dakhoir, Hukum Syariah Compliance di Perbankan Syariah, Yogyakarta: KMedia, 2017.

Akhyar Ari Gayo, dkk, Kedudukan Fatwa MUI dalam Upaya Mendorong Pelaksanaan Ekonomi Syariah, Jakarta: Badan Pembinaan Hukum Nasional Kementerian Hukum dan HAM RI, 2013.

Aqidah Asri Suwarsi, Identifikasi Potensi Nasabah Baru Bank Syariah Ditinjau dari Customer Switching Intentation, Jurnal Ekonomi dan Bisnis Islam, Vol. 3, No. 2 Juli-Desember 2017, h. 170.

Bank Indonesia, Peraturan Bank Indonesia Nomor 13/2/PBI/2011 Tentang Pelaksanaan Fungsi Kepatuhan Bank Umum, Tanggal 12 Januari 2011.

Bank Syariah Mandiri, Laporan Pelaksanaan Good Corporate Governance, Tahun 2011.

${ }^{40}$ Agus Waluyo, Kepatuhan Bank Syariah Terhadap Fatwa Dewan Syariah Nasional Pasca Transformasi ke dalam Hukum Positif, Jurnal Penelitian Sosial IAIN Salatiga, Vol. 10, No. 2, Desember 2016, h. 527-528. 
Direktorat Perbankan Syariah, Outlook Perbankan Syariah Indonesia, 2012, Bank Indonesia.

Fajlurrahman Jurdi, Logika Hukum, Jakarta: Kencana, 2017.

Hajar M. Model-Model Pendekatan dalam Penelitian Hukum dan Fiqh, Yogyakarta: Kalimedia, 2017.

Haniah Ilhami, Pertanggungjawaban Dewan Pengurus Syariah Sebagai Otoritas Pengawas Kepatuhan Syariah Bagi Bank Syariah, Jurnal Mimbar Hukum, Volume 21 Nomor 3, Oktober 2009.

Hennie Van Greuning dan Zamir Iqbal, Analisis Risiko Perbankan Syariah (Risk Analysis For Islamic Banks), Jakarta: Salemba Empat, 2011.

Ibnu Elmi Achmad Slamat Pelu, dan Jefry Tarantang, Fatwa Majelis Ulama Indonesia Sebagai Solusi Permasalahan Umat Islam di Indonesia, Al-Manahij: Jurnal Kajian Hukum Islam, Vol. 14 No. 2, Desember 2020, 307-316 DOI: https://doi.org/10.24090/mnh.v14i2.3927

Jefry Tarantang, Teori dan Aplikasi Pemikiran Kontemporer dalam Pembaruan Hukum Keluarga Islam, Jurnal Transformatif, Vol. 2, No. 1, April 2018.

Luqman Nurhisam, Kepatuhan Syariah (Sharia Compliance) dalam Industri Keuangan Syariah, Jurnal Hukum IUS QUIA IUSTUM No. 1, Vol. 23 Januari 2016.

Luqman Nurhisam, Kepatuhan Syariah (Sharia Compliance) dalam Industri Keuangan Syariah, Jurnal Hukum IUS QUIA IUSTUM No. 1, Vol. 23 Januari 2016.

M. Ali Mansyur, Aspek Hukum Perbankan Syariah dan Implementasinya di Indonesia, Jurnal Dinamika Hukum, Vol. 11 Edisi Khusus Februari 2017.

M. Ali Mansyur, Aspek Hukum Perbankan Syariah dan Implementasinya di Indonesia, Jurnal Dinamika Hukum, Vol. 11 Edisi Khusus Februari 2017.

Moh. Indra Bangsawan, Eksistensi Ekonomi Islam (Studi Tentang Perkembangan Perbankan Syariah di Indonesia), Jurnal Law and Justice Vol. 2, No. 1 April 2017.

Novia, Peran Perbankan Syariah dalam Mengimplementasikan Keuangan Inklusif di Indonesia, Jurnal Etikonomi Vol. 14 No. 2 Oktober 2015.

Peter Mahmud Marzuki, Penelitian Hukum, Jakarta: Kencana, 2010.

Sajipto Rahardjo, Menggagas Hukum Progresif, Semarang: Pustaka Pelajar, 2007.

Undang-Undang No. 21 Tahun 2008 tentang Perbankan Syariah.

Undang-Undang No. 40 Tahun 2007 tentang Perseroan Terbatas.

Wulpiah, Urgensi Penerapan Kepatuhan Syariah Pada Perbankan Syariah (Telaah Konseptual-Analitis), Asy-Syar'iyyah: Jurnal Ilmu Syariah dan Perbankan Syariah, Vol. 2, No. 1 Tahun 2017.

Zamir Iqbal dan Abbas Mirakhor, Pengantar Keuangan Islam: Teori dan Praktek, terj. Oleh A.K. Anwar, Jakarta: Prenada Media Group, 2008. 